\title{
Acidogenic Potential of Packaged Fruit Juices and its Effect on Plaque and Salivary $\mathrm{pH}$
}

\author{
Lata K Mehta ${ }^{1}$, Amitha Hegde ${ }^{2}$, Ann Thomas ${ }^{3}$, Mandeep Singh Virdi ${ }^{4}$
}

\begin{abstract}
Aim: The aim of this study was to analyze the acidogenic potential of the various commercially available fruit juices and to evaluate the salivary and plaque $\mathrm{pH}$ changes before and after consumption of the fruit juices that were kept at various temperatures.

Materials and methods: Baseline plaque and salivary $\mathrm{pH}$ were measured for 30 volunteers, and the test was conducted for 4 consecutive days on which juices with a known $\mathrm{pH}$ was consumed, which were kept at varying temperatures. The resulting changes in the plaque and salivary $\mathrm{pH}$ were measured after 1,5,15, and 30 minutes of the consumption of the fruit juices using a portable standard digital $\mathrm{pH}$ meter.

Results: Among the three juices compared, grape juice was found to be more acidic compared to the orange juice and pineapple juice. The $\mathrm{pH}$ fall was maximum after consumption of grape juice followed by orange and pineapple juice, respectively. The consumption of ice candy caused a greater fall in $\mathrm{pH}$ followed by the refrigerated juice and the juices that were kept at room temperature, respectively.

Conclusion: Parents are unaware of the harmful effects of endogenous acids in the fruit juices and their effect on the teeth. We, as primary dental care providers, should take initiatives to provide adequate knowledge and information regarding this new trend of consuming frozen fruit juices and must strongly discourage this form of consumption as a frequent habit.

Clinical significance: Though many presume that the readily available fruit juices are healthy, frequent consumption of these fruit juices causes acid dissolution of enamel as most of these juices have a pH below the critical level. Hence the present study was conducted to evaluate the erosive potential of the various commercial fruit juices. As with increased awareness by both the dentists and the parents, the problem of fruitjuice-induced tooth loss may be reduced.
\end{abstract}

Keywords: Acidogenic potential, Fruit juices, Plaque $\mathrm{pH}$, Randomized clinical trial, Salivary pH.

International Journal of Clinical Pediatric Dentistry (2019): 10.5005/jp-journals-10005-1644

\section{INTRODUCTION}

With urbanization and exposure to the Western world, Indian consumers today are increasingly becoming conscious of their lifestyle, including food and beverage choices, prompting a shift from colas to healthier options such as juices and milkbased flavored beverages. Fruit juices are slowly becoming an indispensable part of breakfast, social gatherings, picnics, etc., owing to their easy availability, anytime-anywhere consumption, easy-to-carry consumption packs, and convenience. Changing lifestyles, increased health awareness, hygiene concerns, rising disposable incomes, booming modern retail, habitual purchase, and introduction of new flavors are the few reasons behind the growth of the Indian packaged-juice industry. ${ }^{1}$ The role of diet in the etiology of dental erosion has received the most attention in recent years. Dietary acids are undoubtedly the principle causative factor for extrinsic tooth erosion. ${ }^{2}$ The erosive effect of fruit juices has been recognized for a long time, as evident in the studies of Darby ${ }^{3}$ and Miller, ${ }^{4}$ who reported tooth decalcification due to excessive fruit juice consumption. There have been several reports that have raised a concern about an increased prevalence of dental erosion and tooth wear in children, which is mainly related to the marked increase in the consumption of acidic fruit juices, fruit drinks, and carbonated beverages. $^{5}$

Certain lifestyle and behavioral factors should be considered in the etiology of dental erosion such as unusual eating, drinking, and swallowing habits, which increase the direct contact time of acidic foods and beverages with the teeth, increasing the risk of dental erosion. ${ }^{6}$ There is a strong evidence to suggest that the manner in which the acid food or drink is consumed is more important than the

\footnotetext{
1,4 Department of Pedodontics and Preventive Dentistry, PDM Dental College and Research Institute, Bahadurgarh, Haryana, India

2Department of Pedodontics and Preventive Dentistry, AB Shetty Memorial Institute of Dental Sciences, Medical Sciences Complex, Deralakatte, Mangaluru, Karnataka, India

${ }^{3}$ Department of Pedodontics and Preventive Dentistry, AJ Institute of Dental Sciences, Kuntikana, Mangaluru, Karnataka, India

Corresponding Author: Lata K Mehta, Department of Pedodontics and Preventive Dentistry, PDM Dental College and Research Institute, Bahadurgarh, Haryana, India, Phone: +91 9810347547, e-mail: latabanan@hotmail.com

How to cite this article: Mehta LK, Hegde A, et al. Acidogenic Potential of Packaged Fruit Juices and its Effect on Plaque and Salivary pH. Int J Clin Pediatr Dent 2019;12(4):312-317.

Source of support: Nil

Conflict of interest: None
}

overall quantity. Holding, swirling, or retaining acidic drinks and foods in the mouth prolongs the acid exposure on the teeth, increasing the risk of erosion. ${ }^{7}$ Hence the present study has been carried out to assess the acidogenic potential of commonly consumed commercially available fruit juices at various time intervals.

\section{Materials and Methods}

Consent was obtained from the Ethical Committee and the guardians before conducting the study. An estimated 30 volunteers (age: 10-12 years) of either sex were randomly selected. The 
volunteers were selected on the following criteria: DMFT and deft $<3$, simplified oral hygiene index; $<1.2$, no relevant past medical history, and no history of any medication or antibiotic therapy 2 months prior to the study. The volunteers were verbally explained about the procedure and randomly divided into three groups with 10 subjects in each group:

- Group I: 10 children consuming pineapple juice

- Group II: 10 children consuming orange juice

- Group III: 10 children consuming grape juice.

The study was conducted around 9 AM for 4 consecutive days. On the 1st day, a thorough oral prophylaxis was done, and the volunteers were requested to refrain from brushing their teeth or from using any oral hygiene aid for the next 24 hours, and also from eating food or drink for at least 8 hours prior to the procedure. ${ }^{8}$ The volunteers were divided into 3 groups of 10 subjects each and for the next 4 consecutive days salivary and plaque $\mathrm{pH}$ was measured at various intervals after exposing them to the commercially available pineapple, orange, and grape juices kept at room temperature, refrigeration temperature, and freezing temperature, respectively. Day 1: thorough oral prophylaxis was done and for 24 hours no oral hygiene measures were taken.

Day 2: baseline plaque $\mathrm{pH}$ and salivary $\mathrm{pH}$ were measured using a micro pH electrode (Me-5114 Broadly James Custom Electrodes CA, USA). A total of $100 \mathrm{~mL}$ of fruit juice kept at room temperature was consumed (approximately 1 minute). Plaque and salivary $\mathrm{pH}$ were measured after 1, 5, 15, and 30 minutes of consumption of fruit juice (Tropicana fruit juice). Routine oral hygiene measures resumed.

Day 3: the same procedure was undertaken after the consumption of $100 \mathrm{~mL}$ of fruit juice kept in a refrigerator for 4 hours.

Day 4: the same procedure was repeated after the consumption of ice candies prepared from the fruit juices (approx. 5 minutes for consumption).

The obtained data were subjected to statistical analysis, where SPSS software was used to assess the $\mathrm{pH}$ level at different time intervals and expressed as mean $\pm \mathrm{SD}$. Changes in $\mathrm{pH}$ were assessed by Student's unpaired " $t$ " test for the comparisons of interest followed by a multivariate analysis (MANOVA).

\section{Results}

The data obtained in this study were analyzed and the $\mathrm{pH}$ values were estimated in relation to $100 \%$ of the baseline $\mathrm{pH}$. Among the three fruit juices compared, grape juice was found to be more acidic with a $\mathrm{pH}$ of 2.22-2.81 compared to the $\mathrm{pH}$ of orange juice (2.48-3.06) and pineapple juice (2.51-3.91). The frozen fruit juice demonstrated the lowest $\mathrm{pH}$, followed by the refrigerated juice and lastly the juices that were kept at room temperature (Table 1). There was a fall in plaque and salivary $\mathrm{pH}$ within 5 minutes of consumption of these fruit juices. The fall in $\mathrm{pH}$ was maximum with the consumption of grape juice (which was statistically significant) followed by orange and pineapple juice, respectively (Tables 2 and 3). The consumption of ice candy caused a greater fall in plaque and salivary $\mathrm{pH}$ (Fig. 1) followed by the refrigerated juice (Fig. 2) and the juices that were kept at room temperature, respectively (Fig. 3). The multivariate analysis of various commercially available fruit juices (grapes, orange, and pineapple) for comparing the plaque and salivary $\mathrm{pH}$ variation, at different time intervals showed significant $(p<0.05)$ plaque and salivary $\mathrm{pH}$ variation at 1 and 5 minutes of consumption of these commercially available juices that were kept at various temperatures.
Table 1: Recorded $\mathrm{pH}$ values of the commercially available fruit juices

\begin{tabular}{lll}
\hline Juice & Temperature & $\begin{array}{l}\text { pH of commercially } \\
\text { available fruit juice }\end{array}$ \\
\hline Grapes & Room temp. & 2.81 \\
& Refrigerator & 2.62 \\
Orange & Freezer & 2.22 \\
& Room temp. & 3.06 \\
Pineapple & Refrigerator & 2.77 \\
& Freezer & 2.48 \\
& Room temp. & 3.91 \\
& Refrigerator & 2.89 \\
& Freezer & 2.51 \\
\hline
\end{tabular}

There was no significant variation observed at 15 and 30 minutes after the consumption of the earlier-mentioned fruit juices $(p>0.05)$ (Tables 2 and 3$)$.

\section{Discussion}

Consumption of fruits or fruit juices for breakfast is most commonly practiced in our day-to-day life by children and youth. But as the $\mathrm{pH}$ of few fruits is acidic in nature, the acidity of these fruit juices and the demineralization of tooth are directly proportional. An association between the ingestion of acidic drinks and erosion has been recognized. ${ }^{9}$ Though occasional consumption of the fruit juices will have a negligible effect on teeth enamel, but repeated consumption of these fruit juices can cause acid dissolution of enamel as most of these commercially available fruit juices have $\mathrm{pH}$ below the critical level. So the present study was intended to evaluate the endogenous $\mathrm{pH}$ of the various commercially available fruit juices and the plaque and salivary $\mathrm{pH}$ variation at various intervals before and after the consumption of these fruit juices that were kept at different temperatures. The $\mathrm{pH}$ of all the test drinks ranged between 2.22 and 3.91, which were far below the critical $\mathrm{pH}$. This correlates with the $\mathrm{pH}$ values demonstrated by various authors who suggested that fruit-based drinks and fruit juices usually have a $\mathrm{pH}$ range of 3.0-4.0, which causes increased solubility of the tooth enamel, ${ }^{10,11}$ Though the commercial fruit juices in our study was derived from pure, natural products and had no added sugars, colorants, or preservatives, they demonstrated an increased acidity. The acidogenic capacity of the fruit juices cannot be directly related to its $\mathrm{pH}$ because other factors such as different organic acids (e.g., grapes contain maleic and tartaric acid, orange and pineapple contains citric acid), the titrable acidity, phosphate content, and the other weak acids with strong buffering system in the fruit juices may also contribute to its erosive potential. ${ }^{12}$ Moreover, during the processing of these fruit juices, more number of fruits would have been added to make it concentrated so as to maintain its natural taste and to improve the flavor. Among the 3 fruit juices compared, grape juice demonstrated a lower $\mathrm{pH}$ value followed by the orange and pineapple juice. A greater fall in the plaque and salivary $\mathrm{pH}$ was recorded after the consumption of grape juice followed by the orange and pineapple juice, respectively. Similar results were obtained in rat studies, where it was found that canned apple and grape juice were more destructive than pineapple or orange juice. ${ }^{13}$ In another animal study conducted, it was found that grape fruit juice caused more demineralization than plums, mangoes, and pineapple juice. It was also reported that fruit juices were 10 times more destructive than the whole fruit. ${ }^{14}$ Grobler et al. ${ }^{15}$ reported 
Table 2: Multivariate analysis to compare the plaque $\mathrm{pH}$ variation (measured as a mean percentage reduction) in different commercially available fruit juices at different temperatures

\begin{tabular}{|c|c|c|c|c|c|c|c|}
\hline Fruit juices & Time & & $\begin{array}{l}\text { Room } \\
\text { temperature }\end{array}$ & Refrigerator & Candy & $F$ & $p$ \\
\hline \multirow[t]{2}{*}{ Grapes } & 1 minute & Mean & 7.309 & 9.33 & 10.518 & 5.557 & $0.023^{a}$ \\
\hline & & SD & 0.756 & 0.985 & 0.703 & & \\
\hline \multirow[t]{2}{*}{ Orange } & & Mean & 7.241 & 8.561 & 8.605 & & \\
\hline & & SD & 0.743 & 0.692 & 0.688 & & \\
\hline \multirow[t]{2}{*}{ Pineapple } & & Mean & 6.813 & 7.952 & 8.208 & & \\
\hline & & SD & 0.953 & 0.647 & 0.78 & & \\
\hline \multirow[t]{2}{*}{ Grapes } & 5 minutes & Mean & 18.482 & 19.602 & 19.729 & 5.352 & $0.029^{\mathrm{a}}$ \\
\hline & & SD & 1.139 & 1.051 & 1.126 & & \\
\hline \multirow[t]{2}{*}{ Orange } & & Mean & 18.119 & 18.693 & 19.544 & & \\
\hline & & SD & 1.212 & 0.858 & 1.117 & & \\
\hline \multirow[t]{2}{*}{ Pineapple } & & Mean & 17.146 & 17.231 & 19.176 & & \\
\hline & & SD & 0.684 & 0.891 & 0.994 & & \\
\hline \multirow[t]{2}{*}{ Grapes } & 15 minutes & Mean & 9.911 & 13.232 & 13.267 & 0.804 & $0.451^{b}$ \\
\hline & & SD & 3.53 & 2.037 & 2.82 & & \\
\hline \multirow[t]{2}{*}{ Orange } & & Mean & 9.007 & 11.522 & 12.902 & & \\
\hline & & SD & 2.106 & 1.243 & 2.801 & & \\
\hline \multirow[t]{2}{*}{ Pineapple } & & Mean & 9.006 & 11.132 & 12.087 & & \\
\hline & & SD & 1.133 & 2.557 & 1.684 & & \\
\hline \multirow[t]{2}{*}{ Grapes } & 30 minutes & Mean & 5.573 & 7.258 & 7.63 & 4.552 & $0.033^{a}$ \\
\hline & & SD & 3.803 & 2.241 & 2.049 & & \\
\hline \multirow[t]{2}{*}{ Orange } & & Mean & 3.68 & 5.241 & 5.475 & & \\
\hline & & SD & 1.159 & 1.819 & 2.174 & & \\
\hline \multirow[t]{2}{*}{ Pineapple } & & Mean & 3.472 & 4.069 & 5.083 & & \\
\hline & & SD & 1.686 & 1.867 & 2.131 & & \\
\hline
\end{tabular}

that the degree of enamel erosion initiated by the commercial fruit juices is about 5-8 times higher than that of freshly minced fruit juices. Maximum fall in plaque and salivary $\mathrm{pH}$ was recorded in most of the subjects below the critical pH level $(5.5 \pm 0.3)$ within 5 minutes of consumption of these juices, followed by a gradual recovery to the near normal values within 30 minutes of the study. The probable reason for the immediate drop in plaque and salivary $\mathrm{pH}$ after the consumption of the various fruit juices kept at varying temperatures in our study could be attributed to the intrinsic acidity of fruit juices, which rendered it more ability to combat the salivary buffers. When the $\mathrm{pH}$ of the solution is less than the critical $\mathrm{pH}$, the solution is unsaturated, and the mineral from tooth enamel will tend to dissolve until the solution becomes saturated ${ }^{16}$ and the critical $\mathrm{pH}$ is a $\mathrm{pH}$ at which a solution is just saturated with the tooth enamel. However, it is not only the $\mathrm{pH}$ value but also the calcium, phosphate, and fluoride contents of a drink or foodstuff that are important factors in determining the degree of saturation with respect to tooth minerals, which is the driving force for enamel dissolution. ${ }^{17}$ The resting plaque $\mathrm{pH}$ usually ranges between 6 and 7. When a low pH drink is consumed, it causes a fall in this resting plaque $\mathrm{pH}$. The length of time for which this low $\mathrm{pH}$ remains at its minimum is important, since if it reaches the so-called critical $\mathrm{pH}$ value, then it initiates dissolution of the enamel. As the $\mathrm{pH}$ is lowered, the concentration of ions needed for saturation rises, and in the $\mathrm{pH}$ range of around 5.6 the tissues (tooth) will start to dissolve to maintain the saturation. The lower is the $\mathrm{pH}$, faster is the demineralization. ${ }^{18}$

On analyzing our data, it was found that a maximum fall in plaque and salivary $\mathrm{pH}$ occurred after the consumption of frozen fruit juice followed by the refrigerated and room-temperature juices. This also correlates with the findings of various other authors who stated that the consumption of frozen fruit juices can be more deleterious than the unfrozen form. ${ }^{19,20}$ The greater $\mathrm{pH}$ fall after consumption of the frozen fruit juice can also be attributed to a prolonged period of consumption of these fruit juices (approximately 5 minutes), which could expose the teeth to dangerously low levels of $\mathrm{pH}$ as the acid and sugar is held for a prolonged period in contact with the teeth. ${ }^{21}$ The acidity increases as freezing changes the physical state of the residual juice as the solute concentrate (Touyz and Silove). ${ }^{22}$ Acidity reaches a plateau after which it doesn't increase further but rather augments an ability to sustain levels of hydrogen ion activity, i.e., increased buffering capacity. The ingestion of the frozen fruit juice can be considered as highly destructive to teeth as it requires more than usual volume of alkaline salivary buffering actions to raise and normalize the oral environmental $\mathrm{pH}$ (Touyz and Silove). ${ }^{22}$ Thus these findings suggests that the consumption of these frozen fruit juices may cause potential demineralization of tooth structure on prolonged exposure. Though the amount of a fruit juices normally consumed by children may be insignificant, the presence of immature enamel, inadequate neuromuscular 
Table 3: Multivariate analysis to compare the salivary $\mathrm{pH}$ variation (measured as a mean percentage reduction) in different commercially available fruit juices at different temperatures

\begin{tabular}{|c|c|c|c|c|c|c|c|}
\hline Fruit juices & Time & & $\begin{array}{l}\text { Room } \\
\text { temperature }\end{array}$ & Refrigerator & Candy & $F$ & $p$ \\
\hline \multirow[t]{2}{*}{ Grapes } & 1 minute & Mean & 7.412 & 9.324 & 10.751 & 6.659 & $0.002^{b}$ \\
\hline & & SD & 0.453 & 0.775 & 0.704 & & \\
\hline \multirow[t]{2}{*}{ Orange } & & Mean & 7.305 & 8.912 & 9.008 & & \\
\hline & & SD & 0.743 & 0.692 & 0.688 & & \\
\hline \multirow[t]{2}{*}{ Pineapple } & & Mean & 5.563 & 7.851 & 8.095 & & \\
\hline & & SD & 0.923 & 0.647 & 0.78 & & \\
\hline \multirow[t]{2}{*}{ Grapes } & 5 minutes & Mean & 18.482 & 19.602 & 19.729 & 3.352 & $0.046^{\mathrm{a}}$ \\
\hline & & SD & 1.1139 & 1.051 & 1.126 & & \\
\hline \multirow[t]{2}{*}{ Orange } & & Mean & 18.119 & 18.693 & 19.544 & & \\
\hline & & SD & 1.212 & 0.858 & 1.117 & & \\
\hline \multirow[t]{2}{*}{ Pineapple } & & Mean & 17.146 & 17.231 & 19.176 & & \\
\hline & & SD & 0.684 & 0.891 & 0.994 & & \\
\hline \multirow[t]{2}{*}{ Grapes } & 15 minutes & Mean & 9.911 & 13.232 & 13.267 & 3.739 & $0.041^{\mathrm{a}}$ \\
\hline & & SD & 3.53 & 2.037 & 2.82 & & \\
\hline \multirow[t]{2}{*}{ Orange } & & Mean & 9.007 & 11.522 & 12.902 & & \\
\hline & & SD & 2.106 & 1.243 & 2.801 & & \\
\hline \multirow[t]{2}{*}{ Pineapple } & & Mean & 9.006 & 11.132 & 12.087 & & \\
\hline & & SD & 1.133 & 2.557 & 1.684 & & \\
\hline \multirow[t]{2}{*}{ Grapes } & 30 minutes & Mean & 5.573 & 7.258 & 7.63 & 1.712 & $0.187^{c}$ \\
\hline & & SD & 3.803 & 2.241 & 2.049 & & \\
\hline \multirow[t]{2}{*}{ Orange } & & Mean & 3.68 & 5.241 & 5.475 & & \\
\hline & & SD & 1.159 & 1.819 & 2.174 & & \\
\hline \multirow[t]{2}{*}{ Pineapple } & & Mean & 3.472 & 4.069 & 5.083 & & \\
\hline & & SD & 1.686 & 1.867 & 2.131 & & \\
\hline
\end{tabular}

$p$, probability

${ }^{a} p \leq 0.05$ - significant

${ }^{\mathrm{b}} p \leq 0.01$ - highly significant

${ }^{c} p \geq 0.05-$ not significant
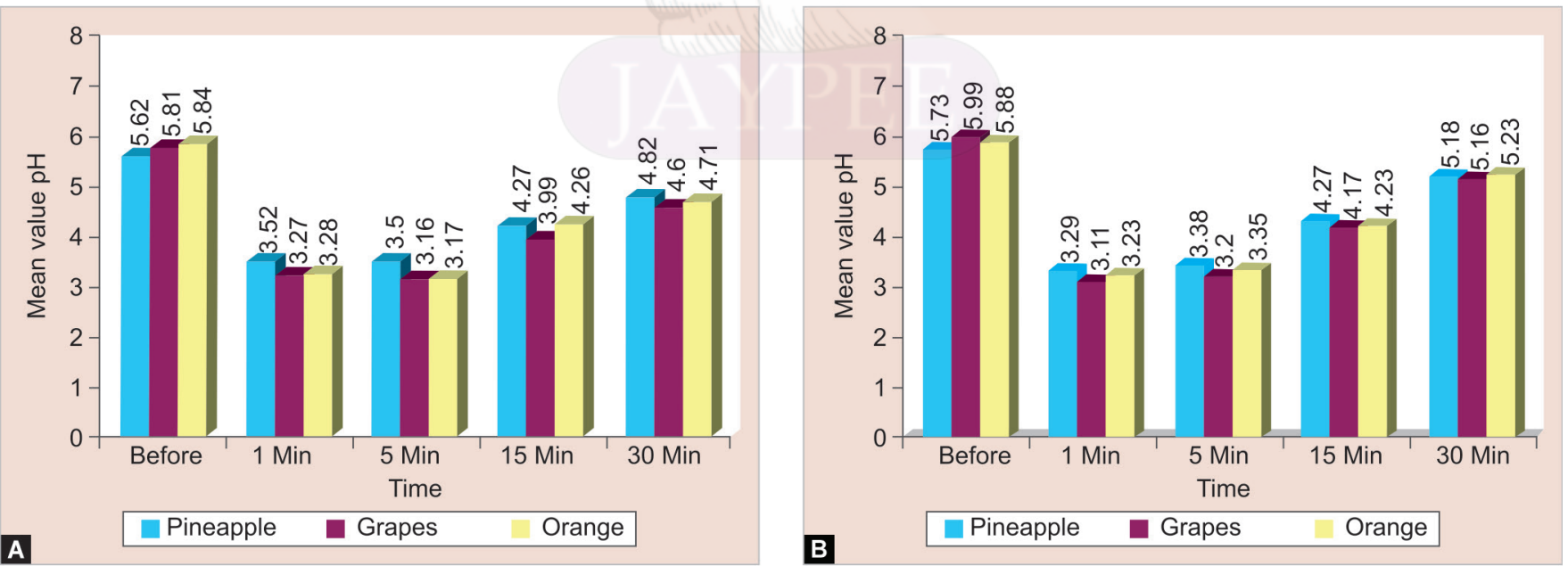

Figs $1 \mathrm{~A}$ and B: Comparison of salivary (A) and plaque (B) $\mathrm{pH}$ variation before and after consumption of ice candies made of different fruit juices

coordination, and inability to clear the retentive substrate, along with the deleterious methods of consumption, make them susceptible to dental erosion. ${ }^{23}$ Theoretically, the erosive potential of a fruit juices may be dependent upon various variables such as the immediate effect of the drink, time taken for its clearance on the tooth, the method of drinking, protective effect of saliva, the amount of residual drink after swallowing, the actual amount of fruit juices consumed, and the frequency of consumption. A single exposure to the acidic attack is of minor importance but frequent consumption of these fruit juices decreases the ability of saliva to deal with the acid attack. It was reported that the solubility of dental tissues increases by a factor of 7-8, with each decrease of 

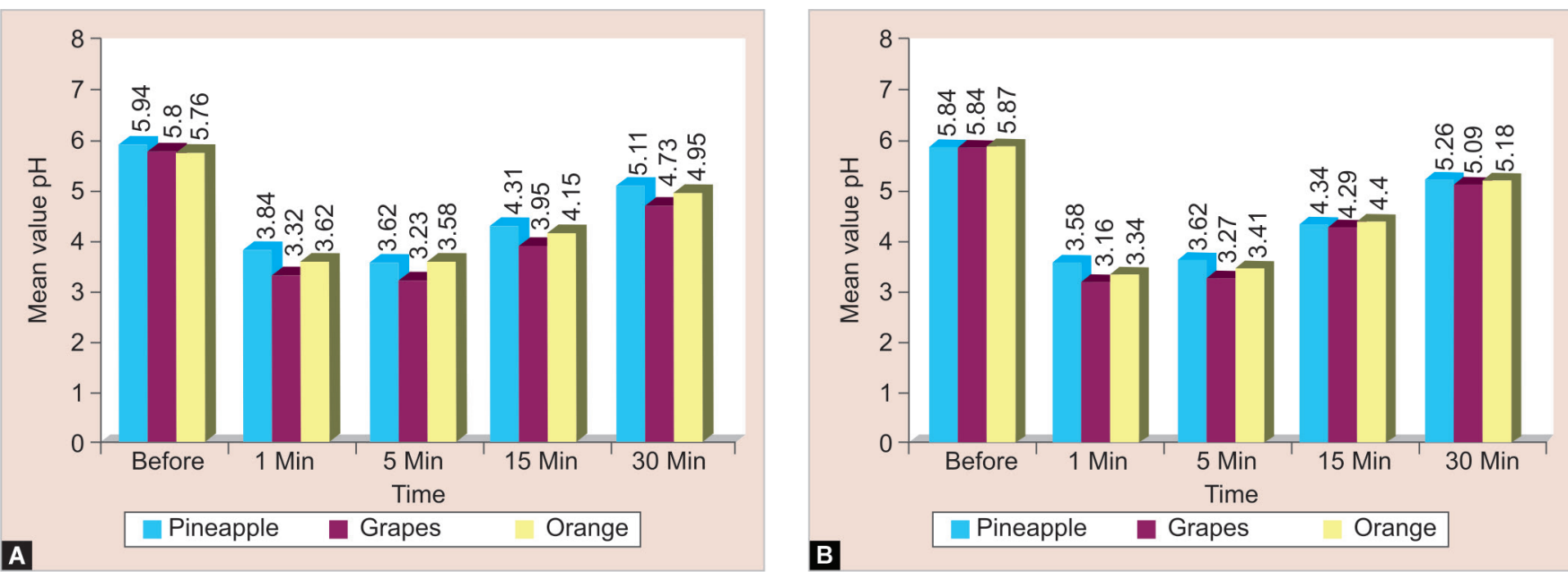

Figs $2 \mathrm{~A}$ and $\mathrm{B}$ : Comparison of salivary (A) and plaque (B) $\mathrm{pH}$ variation before and after consumption of different fruit juices kept in refrigerator
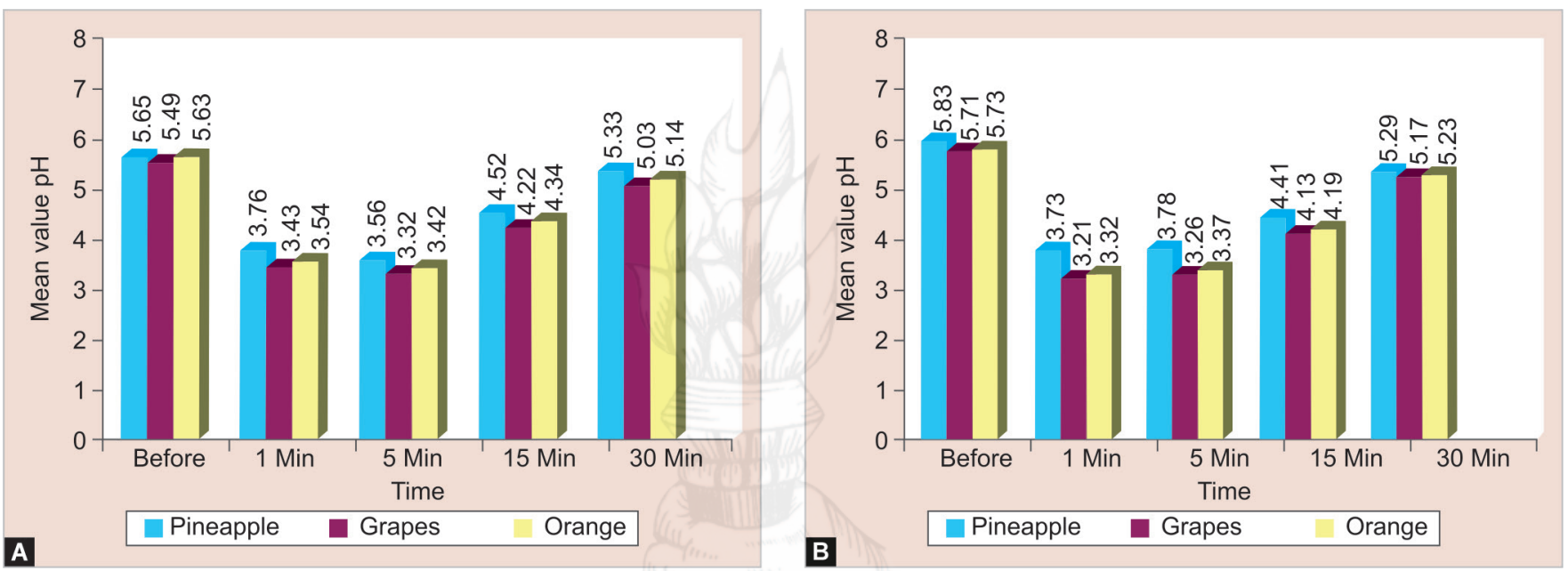

Figs $3 \mathrm{~A}$ and $\mathrm{B}$ : Comparison of salivary $(\mathrm{A})$ and plaque $(\mathrm{B}) \mathrm{pH}$ variation before and after consumption of different fruit juices kept at room temperature

$\mathrm{pH}$ by 1 unit, thereby significantly increasing the potential risk for demineralization. ${ }^{24}$ Hence, the main concern is about the frequent use of acidic fruit juices over time. If the challenge is frequent enough and there are few or no protective factors, this may be aggressive as in caries-susceptible people.

\section{Summary and Conclusion}

The modern fast-track lifestyle has led to an increased consumption of readily available fruit juices. Fruit juice consumption has been popularized as a healthy alternative to other beverages ${ }^{25}$ and this had led to many parents feeding their children with commercially available fruit juices. Children and parents are unaware of the harmful effects of citric acid, malic acid, and tartaric acid on the teeth. Since children are frequently involved in the consumption of these juices and their frozen products, the healthcare providers should take cognizance of this new trend of consuming frozen fruit juices and caution against or strongly discourage this form of consumption as a frequent habit. With increased awareness by dentist and parent, the problem of fruit-juice-induced dental pathology may be reduced.

\section{Clinical Significance}

The growing trend of fitness and keeping oneself healthy has led to a shift in parental preference toward non-carbonated fruit beverages. Though many presume that the readily available fruit juices are healthy, frequent consumption of these fruit juices causes acid dissolution of enamel, as most of these juices have a pH below the critical level. Hence the present study was conducted to evaluate the erosive potential of the various commercial fruit juices. As with the increased awareness by both the dentists and the parents, the problem of fruit-juice-induced tooth loss may be reduced.

\section{References}

1. Verma V, Malhotra M. India's packaged juice market has huge untapped potential Internet. India: FnB news.com; March 04, 2016. Available from: www.fnbnews.com/Top-News/Indias-packagedjuice-market-has-huge-untapped-potential-38596.

2. Ten Cate JM, Imfeld T. Aetiology, mechanism and implications of dental erosion. Eur J Oral Sci 1996 Apr;104(2):149-155. DOI: 10.1111/ j.1600-0722.1996.tb00062.x.

3. Darby ET. Dental erosion and the gouty diathesis: Are they usually associated? Dent Cosmos 1892;34:629-640. 
4. Miller WD. Experiments and Observations on the Wasting of Tooth Tissue variously designated as erosion, abrasion, chemical abrasion, and denudation. Dent Cosmos 1907;49:225-247.

5. Shaw L, Smith A. Erosion in children: An increasing clinical problem? Dent Update 1994 Apr;21(3):103-106.

6. Zero DT. Etiology of dental erosion - extrinsic factors. Eur J Oral Sci 1996;104:162-177. DOI: 10.1111/j.1600-0722.1996.tb00065.x.

7. Moazzez R, Smith BGN, et al. Oral pH, Drinking Habits during ingestion of a carbonated drink in a group of adolescents with dental erosion. J Dent 2000;28:395-397. DOI: 10.1016/S0300-5712(00)00020-8.

8. Duggal MS, Toumba KJ, et al. The acidogenic potential of herbal baby drinks. Br Dent J 1996;180:98-103. DOI: 10.1038/sj.bdj. 4808988.

9. Brown CJ, Smith $\mathrm{G}$, et al. The erosive potential of flavoured sparkling water drinks. Int J Paediatr Dent 2007;17:86-91. DOI: 10.1111/j.1365263X.2006.00784.x.

10. Larsen MJ, Nyvad B. Enamel erosion by some soft drinks and orange juices relative to their $\mathrm{pH}$, buffering effect and contents of calcium phosphate. Caries Res 1999;33:81-87. DOI: 10.1159/000016499.

11. Tahmassebi JF, Duggal MS. The effect of different methods of drinking on the pH of dental plaque in vivo. Int J Paediatr Dent 1997;7:249-254. DOI: 10.1046/j.1365-263X.1997.00054.X.

12. Rytomaa I, Meurman JH, et al. In vitro erosion of bovine enamel caused by acidic drinks and other food-stuffs. Scand J Dent Res 1988;96:324-333.

13. Mc Cay OM, Will L. Erosion of molar teeth by acid beverages. J Nutr 1949;39:313-324. DOI: 10.1093/jn/39.3.319.
14. Miller CD. Erosion of molar teeth by acid beverages. J Nutr 1950;401:63-67. DOI: 10.1093/jn/41.1.63.

15. Grobler SR, Senekal PJ, et al. The degree of enamel erosion by five different kinds of fruit. Clin Prev Dent 1989;2:23-28.

16. Dawes $\mathrm{C}$. What is the critical $\mathrm{pH}$ and why does a tooth dissolve in acid? J Can Dent Assoc 2003;69:722-724.

17. Lussi A, Jaeggi T. Chemical factors. Monogr Oral Sci 2006;20: 77-87.

18. Edgar WM, O'Mullane DM. Saliva and Oral Health, 2nd ed., 1996. pp. 81-84.

19. Holloway PJ, Mellanby M, et al. Fruit drinks and tooth erosion. Br Dent J 1958 May;104:305-309.

20. Touyz LZG, Silove M. Increased acidity in frozen fruit juices and dental implications. J Dent Child 1993 May-June;60(3):223-225.

21. Aebi $H$, Blumenthal $A$, et al. Lebensmittelverbouch in der schweiz; in 2. Schweizeris Cher Ernahrungsbericht. Bern, Huber; 1984. pp. 20-29.

22. Touyz LZG, Silove M. Increased acidity in frozen fruit juices and dental implications. J Dent Child 1993 May-June;60:223-225.

23. Birkhed D. Sugar Content, Acidity and effect on plaque pH of fruit juices, fruit drinks, carbonated beverages and sports drinks. Caries Res 1984;18:120-127. DOI: 10.1159/000260759.

24. Gregory-Head B, Curtis D. Erosion caused by gastro esophageal reflux: diagnostic considerations. J Prosthodont 1997;6:278-285. DOI: 10.1111/j.1532-849X.1997.tb00108.x.

25. Bagde NI, Tumane PM. Studies on microbial flora of fruit juices and cold drinks. Asiatic J Biotechnol Res 2011;2:454-460. 